\title{
Aquatic Macro-invertebrates as Bio-indicators: An Approach for Wetland Water Quality Assessment of Rampur Ghol, Chitwan, Nepal
}

\author{
Birendra Gautam ${ }^{1 *}$, Rejina Maskey (Byanju) ${ }^{1}$, Ramesh Prasad Sapkota ${ }^{1}$, Dharma Raj Dangol ${ }^{2}$ \\ ${ }^{1}$ Central Department of Environmental Science, Tribhuvan University, Kirtipur, Kathmandu \\ ${ }^{2}$ Natural History Museum, Tribhuvan University, Swayambhu, Kathmandu \\ *E-mail: birendragtm@gmail.com
}

\begin{abstract}
The present research was conducted to study seasonal limnological parameters and record composition pattern of aquatic macro-invertebrates of the Rampur Ghol. GRS-BIOS/ASPT index was used to calculate the water quality class, Shannon Weiner diversity index $\left(\mathrm{H}^{\prime}\right)$ and Piélou evenness index $(e)$ were used to determine taxa richness of the macroinvertebrates. Altogether 281 individuals of 14 families and 313 individuals of 18 families were recorded in dry season and rainy season, respectively. Similarly, diversity index and evenness index values were recorded 0.98 and 0.85 in dry season; 1.075 and 0.86 in rainy season. On the basis of different aquatic macro-invertebrates, GRS-BIOS/ASPT Index value of four sampling sites fall in class II (moderately polluted), four sampling sites belong to water quality class IIIII (critically polluted) and remaining two sampling sites belong to water quality class III (heavily polluted). Similarly, in rainy season seven sites fall in water quality class II (moderately polluted) and three sampling sites belong to water quality class II-III (critically polluted).
\end{abstract}

Keywords: Aquatic macro-invertebrates, Evenness Index, Shannon-Weiner Diversity Index, GRS-BIOS/ASPT index

\section{INTRODUCTION}

Wetlands are among the most productive ecosystems in the world and are important for their ecological, economic, cultural and recreational values. These ecosystems produce a wide range of goods and services as well as income generating activities for people all over the world, including Nepal. The wetlands serve as an important habitat for endangered, rare and endemic plant and animal species (Majupuria \& Majupuria, 2006). In recent years, the wetlands are under threat due to human activities that causes to bring about change in water quality which has direct impact in the life pattern of living species. Nepal has freshwater wetlands only, both natural and artificial. Wetlands cover about $5 \%$ of Nepal's land area (Kafle \& Savillo, 2009). Among the wetlands of Nepal, nine lie in the Ramsar sites of international importance. Of the 5358 lakes found in Nepal, 2712 lakes (51\%) are distributed below $500 \mathrm{~m}$ and 2227 (42\%) are in the hills of altitudinal range between $500 \mathrm{~m}$ and $2999 \mathrm{~m}$. Only 419 lakes $(<8 \%)$ are in the hills of above $3000 \mathrm{~m}$ (Bhuju et al., 2009). These wetlands have socioeconomic and socio-cultural values. Nepal's wetlands are under pressure from sedimentation, encroachment and agricultural expansion, water pollution, overuse of wetland resources, eutrophication and poverty (Kafle et al., 2008).

Wetlands of Nepal are very rich in biodiversity of aquatic species and a scenic beauty. Although benthic macro-invertebrates often go unnoticed because of their size and habitat, they are an extremely important part of aquatic ecosystems, and serve as a link in the food web between decomposing leaves and algae, and fish and other vertebrates (Sharma \& Moog, 2005). Macro-invertebrates have important link in the aquatic food web and are valuable indicators in assessments of environmental change (Covich et al, 1999). One major constraint limiting the use of bio-assessment in the Himalayan region is the lack of trained human resources involved in the identification of the biological indicators and also the literatures on Nepalese aquatic fauna are scattered. Almost all the studies on aquatic macro invertebrates are limited to river system and there is lack of studies on such type of marshy land. Because of their ecological and economic significance and their relevant vulnerability to degradation, wetland of Nepal usually the lakes require more attention than is applied to rivers and stream basins. Sustainable use of lakes and reservoirs is being threatened around the globe (World Bank, 1995). Rampur Ghol (freshwater marshland) is also not far from these problems. Anthropogenic activities are very high in this wetland which has posed threats to the water quality, flora and fauna. Realizing the importance of the Ghol for agriculture and fish production, especially for those who live near the Ghol area, this study was conducted to assess the physico-chemical parameters and seasonal composition of macro-invertebrates in both dry season and rainy season. 


\section{MATERIALS AND METHODS}

\section{Study Area}

The Rampur Ghol (freshwater marshy land) lies at latitude of $27^{\circ} 38^{\prime} 14.1^{\prime \prime} \mathrm{N}$ and longitude $84^{\circ} 21^{\prime} 25.2^{\prime \prime} \mathrm{E}$ and at an altitude of $257 \mathrm{~m}$., situated in Chitwan District of Central Nepal (Fig. 1) It is $9 \mathrm{~km}$ south west from the Narayangarh Bazar and the climate over there is sub- tropical. Ghol wetland area covers an area of 15 ha located in Institute of Agriculture and Animal Science and National Maize Research Station of Nepal Agricultural Research Council (NARC) around.

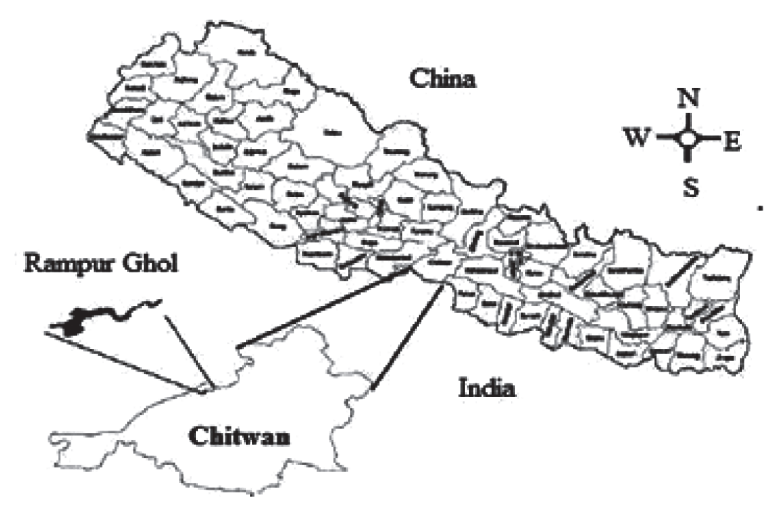

Fig. 1. Map of the study area

\section{Water sample collection and analysis}

Water samples from ten sampling sites of the Ghol area were collected from the surface in clean and rinsed plastic bottles. Physico-chemical parameters viz. Temperature, $\mathrm{pH}$, Dissolved Oxygen (DO), and Electrical Conductivity (EC) were measured at sampling sites by using standard method (APHA, 1998) and other remaining parameter Biochemical Oxygen Demand $\left(\mathrm{BOD}_{5}\right)$, Phosphate-P, Nitrate- $\mathrm{N}$ and Ammoniun-N were determined in the laboratory of Central Department of Environmental Science, Tribhuvan University by using standard method (APHA, 1998, Trivedi \& Goel, 1986).

Aquatic macro-invertebrate sample collection and analysis

A net sampler with 500 micron mesh size was used for sampling. This sampler is developed for Multi Habitat Sampling (MHS) and preferred to Surber sampler (Sharma \& Moog, 2005) because it reduces the amount of sediments in a sample and hence the time for sorting. The net is attached to circular metal frame of area $256 \mathrm{sq}$. $\mathrm{cm}$. Samples collected from muddy and sandy sediments of Ghol were washed thoroughly. The artificial substrate, wood, stones and other detritus was properly checked out. The macro-invertebrates were collected manually by brushes and forceps. Then the collected samples were transferred to specimen collection container, labeled with site code and dates, and finally preserved in $4 \%$ of formaldehyde. The macro-invertebrates so collected were sorted and identified to operational taxonomic level i.e. upto family level using regional keys in the laboratory and microscope for identifying the fauna (Sharma \& Moog, 2005).

\section{Biological Water Quality Class calculation}

Ganga River System Biotic Score per Average Score Per Taxon (GRS-BIOS/ASPT) is calculated by dividing the number of taxa score to the total GRS-BIOS score and the coming numerical value is compared to its transformation table for determination of biological water Quality Classes of running as well as stagnant water bodies (Nesemann, 2006)

Density of macro-invertebrates (D) was calculated by following equation 1 (Odum, 1996)

$\mathrm{D}=\frac{\text { Total Number of Individuals of the Species }}{\text { Sampling area }}$

Shannon index of general diversity formula to find the level of species diversity in an area (Odum, 1996)

Shannon Diversity Index,

$$
\left(H^{\prime}\right)=-\sum \frac{n_{i}}{N} \log \left(\frac{n_{i}}{N}\right)
$$

Where, $n \mathrm{i}=$ Importance value for each species

$$
\mathrm{N}=\text { Total of their importance values }
$$

Evenness index stated by Magurran (1988) as another component of diversity is calculated by using diversity index:

Evenness index is obtained as:

$$
(e)=\frac{H^{\prime}}{\log S}
$$

Where, $H^{\prime}=$ Shannon Weiner Diversity Index $\mathrm{S}=$ Number of species

\section{RESULTS AND DISCUSSION}

The temperature is basically important for its effect on the chemistry and biological reactions in the organisms in waters. The range of temperature is found to be $26.0^{\circ} \mathrm{C}$ to $27.5^{\circ} \mathrm{C}$ in rainy season and $26.0^{\circ} \mathrm{C}$ to $29.1^{\circ} \mathrm{C}$ in dry season (Table 1). A rise in temperature of the water leads to the speeding up of the chemical reactions in water, reduces the solubility of gases and amplifies the odors (Trivedi \& Goel, 1986). Aquatic organism has both an upper and lower temperature limit for optimal growth. This growth is varies from species to species. In present 
study, water temperature of Rampur Ghol show seasonal variation.

The $\mathrm{pH}$ of river water varied between 6.9 to 7.9 in dry season and 6.7 to 7.5 in monsoon season throughout the investigation period. The $\mathrm{pH}$ value of site 6 in the dry season was found to be 7.9. Variation of the $\mathrm{pH}$ may be due to the different anthropogenic activities like animal grazing, fishing etc. During the study period, the value of EC was found to be high in dry season and low in rainy season. The low EC values in rainy season might be due to rainfall in the catchment area and the successive dilution of water. Electrical conductivity is a measure of the ability of an aqueous solution to carry an electric current. This ability depends upon the presence of ions; on their total concentration, mobility and valence; and on the temperature of measurement (APHA, 1995). Runoff and precipitation determine the conductivity. Higher the discharge lowers the conductivity and vice versa. All the values were higher than WHO guideline value (20-30 $\mathrm{mg} / \mathrm{L}$ ) in both dry and rainy seasons.

Table 1. Physio- chemical parameters and biological water quality class (GRS-BIOS/ASPT Index) at different sites in dry season

\begin{tabular}{|c|c|c|c|c|c|c|c|c|c|}
\hline Sites & $\begin{array}{c}\text { Temp } \\
\left({ }^{\circ} \mathrm{C}\right)\end{array}$ & $\mathrm{pH}$ & $\begin{array}{c}\mathrm{EC}(\mu \mathrm{S} / \\
\mathrm{cm})\end{array}$ & $\begin{array}{c}\mathrm{NO}_{3}-\mathrm{N} \\
(\mathrm{mg} / \mathrm{L})\end{array}$ & $\begin{array}{c}\mathrm{PO}_{4}-\mathrm{P} \\
(\mathrm{mg} / \mathrm{L})\end{array}$ & $\begin{array}{c}\mathrm{NH}_{4}-\mathrm{N} \\
(\mathrm{mg} / \mathrm{L})\end{array}$ & $\begin{array}{c}\mathrm{DO} \\
(\mathrm{mg} / \mathrm{L})\end{array}$ & $\begin{array}{c}\mathrm{BOD}_{5} \\
(\mathrm{mg} / \mathrm{L})\end{array}$ & $\begin{array}{c}\text { Biological Water } \\
\text { Quality Class }\end{array}$ \\
\hline 1 & 26.0 & 7.5 & 348 & 0.47 & 0.13 & 0.26 & 4.9 & 16.22 & III \\
\hline 2 & 26.0 & 6.9 & 240 & 0.75 & 0.22 & 0.25 & 6.0 & 8.01 & II-III \\
\hline 3 & 26.7 & 6.8 & 210 & 0.14 & 0.20 & 0.26 & 7.8 & 8.11 & II \\
\hline 4 & 27.2 & 7.5 & 312 & 0.40 & 0.22 & 0.26 & 5.1 & 4.13 & II \\
\hline 5 & 27.5 & 7.4 & 298 & 0.40 & 0.12 & 0.26 & 5.8 & 22.30 & III \\
\hline 6 & 29.1 & 7.2 & 290 & 0.36 & 0.10 & 0.24 & 5.5 & 7.24 & II-III \\
\hline 7 & 29.1 & 7.4 & 295 & 0.34 & 0.11 & 0.26 & 6.2 & 7.12 & II-III \\
\hline 8 & 28.3 & 7.5 & 300 & 0.17 & 0.21 & 0.26 & 7.2 & 16.22 & II \\
\hline 9 & 27.4 & 6.9 & 250 & 0.17 & 0.17 & 0.25 & 7.6 & 8.38 & II \\
\hline 10 & 28.6 & 7.6 & 250 & 0.60 & 0.12 & 0.26 & 5.4 & 14.19 & II-III \\
\hline
\end{tabular}

Table 2. Physico-chemical parameters and biological water quality class (GRS-BIOS/ASPT Index) at different sites in rainy season

\begin{tabular}{|c|c|c|c|c|c|c|c|c|c|}
\hline Sites & $\begin{array}{l}\text { Temp } \\
\left({ }^{\circ} \mathrm{C}\right)\end{array}$ & $\mathrm{pH}$ & $\begin{array}{c}\mathrm{EC} \\
(\mu \mathrm{s} / \\
\mathrm{cm})\end{array}$ & $\begin{array}{l}\mathrm{NO}_{3}-\mathrm{N} \\
(\mathrm{mg} / \mathrm{L})\end{array}$ & $\begin{array}{l}\mathrm{PO}_{4}-\mathrm{P} \\
(\mathrm{mg} / \mathrm{L})\end{array}$ & $\begin{array}{l}\mathrm{NH}_{4}-\mathrm{N} \\
(\mathrm{mg} / \mathrm{L})\end{array}$ & $\begin{array}{c}\mathrm{DO} \\
(\mathrm{mg} / \mathrm{L})\end{array}$ & $\begin{array}{l}\mathrm{BOD}_{5} \\
(\mathrm{mg} / \mathrm{L})\end{array}$ & $\begin{array}{c}\text { Biological Water } \\
\text { Quality Class }\end{array}$ \\
\hline 1 & 27.0 & 7.3 & 220 & 0.19 & 0.05 & 0.25 & 5.1 & 2.03 & II \\
\hline 2 & 27.3 & 7.2 & 227 & 0.27 & 0.08 & 0.30 & 8.5 & 6.08 & II \\
\hline 3 & 27.5 & 6.7 & 212 & 0.24 & 0.06 & 0.28 & 4.9 & 2.01 & II \\
\hline 4 & 27.1 & 6.9 & 215 & 0.17 & 0.05 & 0.25 & 8.3 & 2.03 & II \\
\hline 5 & 27.4 & 7.3 & 225 & 0.33 & 0.04 & 0.32 & 4.8 & 2.02 & II \\
\hline 6 & 27.6 & 7.5 & 180 & 0.31 & 0.47 & 0.52 & 6.8 & 4.05 & II-III \\
\hline 7 & 27.7 & 7.4 & 230 & 0.21 & 0.45 & 0.57 & 6.8 & 4.05 & II-III \\
\hline 8 & 27.4 & 7.3 & 245 & 1.03 & 0.04 & 0.40 & 4.9 & 6.08 & II-III \\
\hline 9 & 27.3 & 7.4 & 230 & 0.24 & 0.45 & 0.44 & 7.3 & 10.13 & II \\
\hline 10 & 27.5 & 7.5 & 225 & 0.25 & 0.32 & 0.40 & 7.0 & 4.05 & II \\
\hline
\end{tabular}

Table 3. Average value of physico-chemical parameters at ten sampling sites with standard deviation value are in $\mathrm{mg} / \mathrm{L}$ except for Temperature, $\mathrm{pH}$ and $\mathrm{EC}$.

\begin{tabular}{|c|c|c|c|}
\hline \multirow{2}{*}{ S.N. } & \multirow{2}{*}{ Parameters } & \multicolumn{2}{|c|}{ (Mean \pm S.D) } \\
\cline { 2 - 4 } & & $27.7 \pm 1.04$ & Rainy Season \\
\hline 1 & Temperature ${ }^{\circ} \mathrm{C}$ & $277 \pm 3.86$ & $27.4 \pm 0.22$ \\
\hline 2 & $\mathrm{EC}(\mu \mathrm{S} / \mathrm{cm})$ & $6.0 \pm 0.9$ & $218 \pm 1.62$ \\
\hline 3 & $\mathrm{DO}(\mathrm{mg} / \mathrm{L})$ & $11.2 \pm 5.7$ & $4.9 \pm 1.6$ \\
\hline 4 & $\mathrm{BOD}_{5}(\mathrm{mg} / \mathrm{L})$ & $0.16 \pm 0.05$ & $0.20 \pm 0.20$ \\
\hline 5 & $\mathrm{PO}_{4}-\mathrm{P}(\mathrm{mg} / \mathrm{L})$ & $0.38 \pm 0.20$ & $0.32 \pm 0.25$ \\
\hline 6 & $\mathrm{NO}_{3}-\mathrm{N}(\mathrm{mg} / \mathrm{L})$ & $0.26 \pm 0.07$ & $0.43 \pm 0.23$ \\
\hline 7 & $\mathrm{NH}_{4}-\mathrm{N}(\mathrm{mg} / \mathrm{L})$ & & \\
\hline
\end{tabular}


Oxygen is an important parameter to the metabolism of all aquatic organisms that possess aerobic respiration. Concentration of DO indicates water quality and its relation to the distribution and abundance of various algal species (Sisodia and Moundiotiya, 2006). Its presence is essential to maintain the higher forms of biological life in the water (Trivedi and Goel, 1986). The DO in the water samples ranged from $4.8 \mathrm{mg} / \mathrm{L}$ to $7.6 \mathrm{mg} / \mathrm{L}$ in dry season and $4.8 \mathrm{mg} / \mathrm{L}$ to $8.3 \mathrm{mg} / \mathrm{L}$ in rainy season. DO value was increased from dry season to rainy season. Similar results were observed in Bagmati river system by ENPHO (1997) and Shrestha (2007). The study exposed that DO at all sampling sites were above $4 \mathrm{mg} / \mathrm{L}$ and hence the water is suitable for drinking, bathing, aquaculture and irrigation (Radhika et al., 2004).

The $\mathrm{BOD}_{5}$ was found to be higher in dry season which may due to the low water table that increased the concentration of organic load. Unpolluted waters typically have $\mathrm{BOD}_{5}$ values of $2 \mathrm{mg} / \mathrm{L}$ or less (UNESCO, 1996). The optimum $\mathrm{BOD}_{5}$ range for fisheries and aquatic life is less than $15 \mathrm{mg} / \mathrm{L}$ (GoN/FDD, 1998). A high waste discharge in organic matter and nutrients can lead to decrease in DO concentrations as a result of increased microbial activity occurring during the degradation of the organic matter. High content of $\mathrm{BOD}_{5}$ cause oxygen depletion, which leads to the suffocation of the aquatic life (Verma et al. 1984). Since the values of $\mathrm{BOD}_{5}$ in rainy season in all sites were recorded within the permissible limits thus indicating presence of decomposable organic matter in the Ghol area is suitable for aquaculture.

Nitrate-Nitrogen is essential for living organisms as an importance for protein formation, including genetic materials. Nitrate- $\mathrm{N}$ is the intermediate state of nitrogen. In natural conditions, the $\mathrm{NO}_{3}-\mathrm{N}$ concentration seldom exceeds $0.1 \mathrm{mg} / \mathrm{L}$ (UNESCO, 1996). In the investigation period of dry season site 2 was more or less in similar to natural condition. Similarly, rainy season of site 1 , site 2 , site 3 , site 4 and site 5 were in natural condition.

Phosphate-P is an essential nutrient for living organism and exists in water bodies as both dissolved and particulate species. In natural waters and waste waters, phosphorous occurs mostly as dissolved orthophosphates and polyphosphates, and organically bound phosphates (UNESCO, 1996 and APHA, 1995). Natural source of phosphorous in the wetland is due to the decomposition of organic matter. In most of the natural water, phosphorous ranges from 0.005 to $0.020 \mathrm{mg} / \mathrm{L} \mathrm{PO}_{4}-\mathrm{P}$ (GoN/FDD, 1998). During the present investigation the highest concentration of phosphorous was found during rainy season $0.47 \mathrm{mg} / \mathrm{L}$ at site 6 and lowest during dry season i.e. $0.01 \mathrm{mg} / \mathrm{L}$ at site 6 . This was evidently due to the surface runoff from the surrounding fish pond and crop fields fertilized with phosphate. $0.02 \mathrm{mg} / \mathrm{L}$ is considered to be factor for accelerating eutrophication in lake (WHO, 1993).

The ammonium-N concentration in Ghol area was found to be high in rainy season and low in dry season. The agricultural site contributed high ammonia concentration in rainy season. The values ranged from $0.24 \mathrm{mg} / \mathrm{L}$ to $0.26 \mathrm{mg} / \mathrm{L}$ in dry season and $0.25 \mathrm{mg} / \mathrm{L}$ to $0.57 \mathrm{mg} / \mathrm{L}$ in rainy season. This result resembles to the study carried by Shahi (2012) in different lakes of Pokhara. In contrast the value was found opposite to the result of (Ali, 2002) where there is high ammonia value in hot season. They reported that the ammonia concentrations increase during hot period over cold seasons in toxic condition. The relative decrease in the ammonia concentrations during cold seasons were related to the oxidation of the ammonia by oxygen rich rather than uptake of ammonia by the phytoplankton cells (Shabana, 1999). Unpolluted water contains small amounts of $\mathrm{NH}_{3}-\mathrm{N}$ usually less than 0.1 $\mathrm{mg} / \mathrm{L}$ (UNESCO, 1996). Optimal ammonical nitrogen of water for fishes is less than $0.3 \mathrm{mg} / \mathrm{L}$ (GoN/FDD, 1998). Thus the Rampur Ghol is suitable for aquaculture.

\section{Biological Water Quality Class (GRS-BIOS/ASPT Index)}

Analyzing the GRS-BIOS/ASPT index in dry season four sites i.e. site 3 , site 4 , site 8 and site 9 fall in water quality class II and four sampling sites i.e. site 2, site 6 , site 7 and site 10 belong to water quality class II-III and remaining two sampling sites i.e. site 1 and site 5 belong to III. This indicates that most of the Ghol water is moderate to heavily polluted. Similarly in rainy season seven sites i.e. site 1 , site 2 , site 3 , site 4 , site 8 , site 9 and site 10 fall in class II and three sampling sites i.e. site 5 , site 6 and site 7 lie in water quality class II-III. This indicates that most of the Ghol water is moderate to critically polluted. This might be due to favorable conditions for wide range of pollutant tolerant species. In dry season the water quality class ranges from class II to water quality class III but in rainy season, water quality class II and water class II-III were assessed. It shows that water is less polluted in rainy season than that of the dry season. In dry season site 1 and site 5 were found to be more polluted than the other sites. This might be due to the presence of family Tubificidae and Chironomidae. The species of these families are found in water quality of class III and even in heavily polluted running water of class IV (Gaufin, 1958 \& Shrestha, 2007) 


\section{Aquatic macro-invertebrates}

Aquatic macro-invertebrates indicate biological response to increasing levels of stressors throughout their stages. Some of these stages are more sensitive than others to particular stressors responding quickly to stress during a sensitive stage of life (Badruzzaman et al., 2007). Aquatic macro-invertebrates as bio-indicators have a wide range of pollutant tolerances among the various species therefore are well suited for the assessment of site specific pollution impacts and to determine the water quality. During study period altogether 281 individuals of 14 taxa (family) belonging to 10 orders were found in dry season where as in rainy season 313 individuals of 18 taxa (family) belonging to 12 orders were found within the Ghol area as presented in Table 4.

Table 4. Total number of taxa, Density, Shannon Weiner Diversity index and Evenness index in dry season and rainy season.

\begin{tabular}{|c|c|c|c|c|c|c|c|c|}
\hline \multirow{2}{*}{$\begin{array}{l}\text { Name of Taxa } \\
\text { (Family) }\end{array}$} & \multicolumn{4}{|c|}{ Dry Season } & \multicolumn{4}{|c|}{ Rainy Season } \\
\hline & $\begin{array}{c}\text { Total no. } \\
\text { of taxa }\end{array}$ & $\begin{array}{l}\text { Density } \\
\left(\text { ind } / \mathrm{m}^{2}\right)\end{array}$ & $\begin{array}{c}\text { Diversity } \\
\text { index (H') }\end{array}$ & $\begin{array}{l}\text { Evenness } \\
\text { index (e) }\end{array}$ & $\begin{array}{l}\text { Total no. of } \\
\text { taxa }\end{array}$ & $\begin{array}{l}\text { Density } \\
\left(\mathrm{ind} / \mathrm{m}^{2}\right)\end{array}$ & $\begin{array}{l}\text { Diversity } \\
\text { index (H') }\end{array}$ & $\begin{array}{l}\text { Evenness } \\
\text { index (e) }\end{array}$ \\
\hline Salifidae & 0 & 0 & \multirow{19}{*}{0.98} & \multirow{19}{*}{0.85} & 3 & 11.72 & \multirow{19}{*}{1.075} & \multirow{19}{*}{0.86} \\
\hline Gomphidae & 2 & 7.81 & & & 20 & 78.12 & & \\
\hline Lymnaeidae & 14 & 54.69 & & & 52 & 203.125 & & \\
\hline Dytiscidae & 18 & 70.3 & & & 56 & 218.75 & & \\
\hline Viviparidae & 13 & 50.78 & & & 12 & 46.875 & & \\
\hline Unionidae & 16 & 62.5 & & & 2 & 7.8125 & & \\
\hline Amphullariidae & 25 & 97.66 & & & 34 & 132.81 & & \\
\hline Baetidae & 2 & 7.81 & & & 49 & 191.41 & & \\
\hline Protoneurodae & 0 & 0 & & & 13 & 50.78 & & \\
\hline Gerridae & 1 & 3.91 & & & 2 & 7.81 & & \\
\hline Potamidae & 0 & 0 & & & 3 & 11.72 & & \\
\hline Thiaridae & 70 & 273.4 & & & 27 & 105.47 & & \\
\hline Mycidae & 0 & 0 & & & 4 & 15.62 & & \\
\hline Tubificidae & 10 & 39.06 & & & 4 & 15.625 & & \\
\hline Chironomidae & 7 & 27.34 & & & 2 & 7.8125 & & \\
\hline Assiminadae & 35 & 136.72 & & & 8 & 31.25 & & \\
\hline Planerbadae & 22 & 85.93 & & & 18 & 70.3125 & & \\
\hline Sphaeriidae & 45 & 175.78 & & & 14 & 54.68 & & \\
\hline Total & 281 & & & & 313 & & & \\
\hline
\end{tabular}

The density of aquatic macro-invertebrates in most stations increased during the rainy season. It may be because of recruitment and growth of young (Hynes, 1979). However, the density of macro-invertebrates decreased during the dry. It may be so because the growth of many individuals slows down in dry and winter and the rate of recruitment from newly hatched eggs also declines. The benthic population of aquatic taxa was dominated by order Prosobranchia comprising 3 families i.e. Thiaridae, Viviparidae, and Ampulariidae in dry and rainy season where as taxa of order Herptera were found least in dry season but taxa of order Diptera and Herptera were found least in rainy season. However, taxa belonging to order Hirudinea were absent in dry season. The family Baetidae was abundantly recorded in clean and less polluted sites (in site 8 in dry season) and it was found in all sites except site 5 , site 7 and site 8 in rainy season as indicated by water quality class using GRSBIOS/ASPT water quality index and were almost absent in highly polluted sites (site 5 , site 7 and site 8 ). It may be because Baetidae is intolerant species to organic pollution (Gaufin, 1958; Shrestha, 2007).

The family Thiaridae was found in all sites except site 1. Similarly the species of family Viviparidae was also abundantly found except in site 1 and site 2 . This support the fact that the family Viviparidae, Thiaridae and Ampulariidae (Pila globosa) of order Prosobranchia indicates moderately tolerant of organic enrichment (Badruzzaman et al., 2007). Sphaeriidae and Unionidae families under the order Eulamellibranchia are abundant in water enriched with organic nutrients and medium to low in dissolved oxygen some species of these families 
are very tolerant of poor water quality (Badruzzaman et al., 2007). The species of these families were abundantly found in most of the study sites.

Tubificidae families found in the samples under the class of Oligochaeta have a greatest indicator value. The species of this family were found in water quality of class III and even in heavily polluted running water of class IV (Badruzzaman et al., 2007; Shrestha, 2007). This supports our results. Crustaceae are intolerant or moderately tolerant of organic pollution. Mycidae, Potamidae live in clean water and moderately tolerant of pollution. Most of these families found in water quality class II and even in critically polluted running water of class III (Alam et al., 2008).

Odonata found in a number of samples exhibits a range of sensitivity to pollution. The larvae of Gomphidae, Protonerodae, Lebellulidae have been found outside the thermal plume, are intolerant of pollution and indicate moderate water quality (Badruzzaman et al., 2007; Alam et al., 2008). Chironomidae family under the order Diptera are poor tolerant of organic and inorganic pollution (Sharma et al., 2009). Chironomidae was found in the two sites of water quality class III indicating heavily polluted water. Chironomidae is commonly known as midges, are the most common of aquatic invertebrates of aquatic environment and indicate multiple stressors (Gaufin, 1958; Shrestha, 2007).

The value of Shannon Weiner diversity index was found to be highest in rainy season and where as it was found lowest in dry season. This is due to the fact that in rainy season the flow of water table might have provided suitable environment for the macro-invertebrates and low human disturbance. The value of evenness index was found to be highest in rainy season and where as it was found lowest in dry season. The highest value indicates the homogeneity of the aquatic macro-invertebrates and lower value indicates the heterogeneity of the aquatic macro-invertebrates which are directly influenced by anthropogenic activities.

\section{CONCLUSION}

It is the first study carried out in Rampur Ghol of Institute of Agriculture and Animal Science by using benthic macro-invertebrates as major biological water quality assessment tool. Assessing the biological water quality class (GRSBIOS/ASPT Index) in dry season four sampling sites fall in water quality class II i.e. moderately polluted, four sampling sites belong to water quality class II-III i.e. critically polluted and remaining two sampling sites belong to water quality class III i.e. heavily polluted. Similarly, in rainy season seven sites fall in water quality class II i.e. moderately polluted and three sampling sites lies water quality class II-III i.e. critically polluted. During study period altogether 281 individuals of 14 families belonging to 10 orders of aquatic macro-invertebrate were recorded in dry season and 313 individuals of 18 families belonging to 12 orders of aquatic macro-invertebrates were recorded in rainy season. Family Thiaridae was recorded highest density in dry season and family Dytiscidae was recorded highest density among all families in rainy seasons. The Rampur Ghol is rich in terms of aquatic macro-invertebrates taxa composition and its diversity.

\section{ACKNOWLEDGEMENTS}

This research is supported by University Grant Commission (UGC) funded institutional project entitled Rampur Ghol Project awarded to Institute of Agriculture and Animal Science, Tribhuvan University, Rampur, Chitwan. We would like to thank Bam Bahadur Oli for his assistance in field work and Department of Aquaculture, Institute of Agriculture and Animal Sciences, Chitwan and Central Department of Environmental Science, Kirtipur for providing laboratory facilities.

\section{REFERENCES}

Alam, M.S., Hoque, M.M., Bari, M.F., Badruzzaman, A.B.M., Alam, M.S. and Habib, M.E. 2008. Aquatic macro-invertebrates as bio-indicators: A new approach for river water quality assessment in Bangladesh. Proceedings of the Scientific Conference: Rivers of the Hindu Kush HimalayaEcology and Environmental Assessment. Pp. 131136.

Ali, M.H.H. 2002. Impact of Agricultural and Sewage Effluents on the Ecosystem of Lake Qarun, Egypt. Ph.D. Thesis. Faculty of Science, Al-Azhar University, Egypt.

APHA 1998. Standard Method for the Examination of Water and Waste Water. 20 th edition. American Public Health Association, Washington D.C.

Bach, E. 1980 in Doetsch, P. 1987, Entwicklung und exemplarische Anwendung eines Verfahrens zur nutzungsadäquaten Quantifizierung Von Gewässergüte. Hochschulreibe Aachen, Gewässerschütz - wasser - Abwasser, 91p.

Badruzzaman, A.B.M., Bari, M.F., Alam, M.S., Hoque, M.M., Habib, M.E. and Saha, M. 2007. Effects of thermal effluent discharge on the macroinvertebrate abundance in the Sitalakhya river in Bangaladesh. Proceedings of the Scientific Conference; Rivers of the Hindu-Kush Himalaya- Ecology and Environmental Assessment. 113p. 
Bhuju, U.R., Khadka, M., Neupane, P.K. and Adhikari, R. 2009. Lakes of Nepal: 5358- Map Based Inventory. National Lakes Conservation Development Committee, Kathmandu.

Covich, A.P., Palmer, M.A. and Crowl, T.A. 1999. The role of benthic invertebrate species in freshwater ecosystem. Journal of Bioscience 49: 119-127.

ENPHO 1997. Monitoring and Assessment of Water Quality in the Shivapuri Watershed. HMG/FAO Shivapuri Integrated Watershed Development Project (GCP/ NEP/048/NOR), Environment and public Health Organization pp i- xiii, 1- 125, 196 - 145.

Gaufin, A.R. 1958. The effects of pollution of a midwestern stream. Ohio Journal of Science, 58: 197-208

GoN/FDD 1998. Matsya Prasar Karakartako Laagi: Matsya Palan Srinkhala No. 2 (for Fisheries Extension Workers, Fish Farming Series No. 2), GoN/Fisheries Development Division (FDD), Kathmandu, Nepal.

Hynes, H.B.N. 1979. Ecology of Running Waters. Liverpool University Press, Liverpool.

Kafle, G. and Savillo, I.T. 2009. Present status of Ramsar sites in Nepal. International Journal of Biodiversity and Conservation 1(5): 146-150.

Kafle, G., Balla, M.K. and Paudyal, B.K. 2008. A review of threats to Ramsar sites and associated biodiversity of Nepal. FAO Tiger Paper 35(1): 9-11.

Magurran, A.E. 1988. Ecological Diversity and its Measurement. Princeton University Press, Princeton.

Majupuria, T.C. and Majupuria, R.K. 2006. Wildlife and Protected Areas of Nepal. S. Devi, Bajoria Road, Opposite Saharanpur (U.P.), India.

Nesemann, H., 2006. Macroinvertebrate Non-insecta's Fauna and their Role in Biomonitoring of the Ganga River System (with illustrated key including 679 figures). M.Sc. Thesis. Department of Environmental Science and Engineering, Kathmandu University, Nepal, Pp 85-114.

Odum, E.P. 1996. Fundamentals of Ecology. Third Edition 1971 and First Indian Edition 1996. Natraj Publishers, Dehra Dun, India, pp 148-154.

Radhika, C., Mini, I. and Devi, T.G. 2004. Abiotic parameters of a tropical freshwater lake Vellayani-Trivandrum, Kerala. Journal of Pollution Resources 23:49-68.

Shabana, E. E. 1999. Limnological Studies on Lake Bardawil. M. Sc. Thesis. Faculty of Science, Suez Canal University, Egypt.

Shahi, A. 2012. Wetland Conservation through Water Quality Assessment and Willingness to Pay: A Case of Baral Danda Lake Complex, Kaski, Nepal, M.Sc. Thesis. Central Department of Environmental Science, Tribhuvan University, Kirtipur, Kathmandu, Nepal.
Sharma, S. and Moog, O. 2005. A reference based Nepalese biotic score and its application in the midland hills and lowland plains for river water quality assessment and management. edited by Tripathi, R.D., Kulshrestha, K., Agrawal, M., Ahmed, K.J., Varsehen, C.K., Fripa, Sagar and Pushpangadan (eds.), Proceedings of Plant Response to Environmental Stress. IBD CO. Publisher, Lucknow. Pp 105-112

Sharma, S., Moog, O., Nesemann, H. and Pradhan, B. 2009. Application of Nepalese biotic score and its extension for river water quality management in the Central Himalaya, Nepal. Paper presented at The International Symposium on Environment, Energy and Water in Nepal: Resent Researches and Direction for Future, Kathmandu, Nepal.

Shrestha, G.K.C. 2007. Assessment of Water Quality of Manahara River, Kathmandu Valley by Using Macroinveritbrates as Biological Indicators. M.Sc. Thesis, Central Department of Environmental Science, Tribhuvan University, Kritipur, Kathmandu, Nepal.

Sisodia, R. and Moundiotiya, C. 2006. Assessment of the water quality index of wetland Kalakho lake, Rajasthan, India. Journal of Environmental Hydrology 14: 23. at http://www.hydroweb.com

Trivedi, R.K. and Goel, P.K. 1986. Chemical and Biological Methods for Water Pollution Studies. Department of Environmental pollution, Karad, India.

UNESCO 1996. Water Quality Assessments- A Guide to Use of Biota, Sediments and Water in Environmental Monitoring- Second Edition, Chapman, D. (ed.) on behalf of United Nations Educational, Scientific and Cultural Organization (UNESCO), World Health Organization.

Verma, S.R., Sharma, P., Tyagi, A., Rani, S.S., Gupta, A.K. and Dalela, R.C. 1984. Pollution and saprobic status of eastern Kalinadi. Limnology 15:69-133.

WHO 1993. Guidelines for Drinking Water Quality. Recommendation. Second edition, World Health Organization (WHO), Geneva. Vol.1.

World Bank 1995. Restoring and Protecting the World's Lakes and Reservoirs. The World Bank, Washington D.C., World Bank Technical Paper Number 289. 